\title{
Lyophilized autologous serum stabilized with sucrose promotes the proliferation and migration of keratinocyte
}

\author{
Iman Permana Maksum ${ }^{*}$ (D), Siti Jubaedah ${ }^{1}$, Yosua Yosua $^{1}$, Rostina Melpin $^{1}$, Mervina Rondonowu ${ }^{1}$, Sutarya Enus ${ }^{2,3}$, \\ Saadah Diana Rachman ${ }^{1}$, Sriwidodo Sriwidodo ${ }^{4}$, Toto Subroto ${ }^{1}$ \\ ${ }^{1}$ Department of Chemistry, Faculty of Mathematics and Natural Science, Universitas Padjadjaran, Sumedang, Indonesia. \\ ${ }^{2}$ Department of Ophthalmology, Faculty of Medicine, Universitas Padjadjaran, Sumedang, Indonesia. \\ ${ }^{3}$ National Eyes Center, Cicendo Eyes Hospital, Bandung, Indonesia. \\ ${ }^{4}$ Department of Pharmaceutics and Pharmaceutical Technology, Faculty of Pharmacy, Universitas Padjadjaran, Sumedang, Indonesia.
}

\begin{tabular}{|c|c|}
\hline ARTICLE INFO & ABSTRACT \\
\hline $\begin{array}{l}\text { Received on: } 11 / 01 / 2021 \\
\text { Accepted on: } 22 / 04 / 2021 \\
\text { Available online: } 05 / 07 / 2021\end{array}$ & $\begin{array}{l}\text { The autologous serum is widely used as therapy for epithelial cell treatment and dry eye syndrome due to its } \\
\text { epitheliotropic properties, which are similar to tears. The serum contains human epidermal growth factor (hEGF) } \\
\text { and retinol, which play important roles in cell proliferation and differentiation. Freeze-drying improves the stability } \\
\text { of therapeutic proteins for long-term storage. Sucrose is known to stabilize protein during freeze-drying and storage. }\end{array}$ \\
\hline $\begin{array}{l}\text { Key words: } \\
\text { Autologous serum, cell } \\
\text { proliferation and migration, } \\
\text { freeze-drying, hEGF, sucrose, } \\
\text { vitamin E. }\end{array}$ & $\begin{array}{l}\text { Also, antioxidants such as vitamin E can maintain unstable retinol levels. This study aims to investigate the effect of } \\
\text { the addition of sucrose to preserve dried autologous serum during freeze-drying and storage, as well as the effects of } \\
\text { the serum on keratinocyte proliferation and migration. The addition of sucrose to autologous serum could preserve the } \\
\text { dried autologous serum components above the minimum requirement for substitute tears after } 6 \text { months of storage. } \\
\text { The highest cell proliferation was achieved by the addition of } 25 \mathrm{ng} / \mathrm{ml} \mathrm{hEGF} \text { and } 1 \% \text { vitamin E, while the highest } \\
\text { migration activity was achieved by the addition of } 25 \mathrm{ng} / \mathrm{ml} \mathrm{hEGF} \text {. Freeze-drying autologous serum with the addition } \\
\text { of sucrose and storage at low temperatures can extend its shelf life. Also, the addition of exogenous hEGF and vitamin } \\
\text { E to autologous serum can increase the proliferation and migration of keratinocyte cells. }\end{array}$ \\
\hline
\end{tabular}

\section{INTRODUCTION}

Autologous serum is recommended as eye drops for ocular surface disorder treatments, such as Sjörgen syndrome, a tear production disorder, and non-Sjörgen syndromes, such as graft-versus-host, neurotrophic keratitis, epithelial persistent defect, and superior limbic keratoconjunctivitis (Koffler, 2006). It is widely used in ophthalmology as a tears substitute, not only to lubricate the ocular surface but also to provide other components not present in patients with ocular surface disorders (López-García et al., 2007). Autologous serums are prepared from blood; so, they are natural, do not cause allergic reactions, and

"Corresponding Author

Iman Permana Maksum, Department of Chemistry, Faculty of Mathematics \& Natural Science, Universitas Padjdadjaran, Sumedang, Indonesia.E-mail: iman.permana@unpad.ac.id have biomechanical and biochemical properties similar to tears. Some components of autologous serum that are similar to tears are epidermal growth factor (EGF), transforming growth factor- $\beta$ (TGF- $\beta$ ), immunoglobulin A, vitamin A, fibronectin, cytokine, and lysozyme (Geerling et al., 2004; Quinto et al., 2008), which are important to maintain the cornea and conjunctival epithelium health (Koffler, 2006). However, autologous serum in drop form has a shelf life of 1 month, 3 months if stored at $-20^{\circ} \mathrm{C}$ (HerreroVanrell \& Molina-Martínez, 2008). Therefore, another storage method is needed to enhance stability over time, while also maintaining its convenience and portability.

Freeze-drying, also known as lyophilization, can improve the long-term stability of therapeutic proteins (Tang \& Pikal, 2004), as chemical and physical degradation is inhibited in freezedried solid form (Carpenter et al., 1997). Besides its advantage in terms of stability, lyophilized solid forms are also much easier to handle, package, and transport (Tang \& Pikal, 2004). Protection of the conformation of the protein during freeze-drying through the 
appropriate control of the process and optimization of the material is important to preserve the pharmacological effects and reduce the immunogenicity of the product (Hermeling et al., 2004). Nonreducing sugar, like sucrose, acts as stabilizers, protecting the protein from chemical and physical degradation in aqueous solution during freeze-drying and subsequent storage (Carpenter \& Crowe, 1989; Wang, 2000).

Vitamin A is essential for vision as well as cell growth and differentiation (Amann et al., 2011), with as much as 95\% of vitamin $\mathrm{A}$ in the blood in the form of retinol (Catignani et al., 1983). Inside the cell, it is oxidized to retinoic acid which plays an important role in cell growth and differentiation (Amann et al., 2011; Zasada \& Budzisz, 2019). Retinol in dried autologous serum has a relatively short shelf life due to oxidation (Maksum et al., 2016) but can be stabilized by the addition of vitamin E (Maksum et al., 2018). However, the effect of vitamin E added to the activity of autologous serum is still unknown.

Human epidermal growth factor (hEGF) also plays an important role in the proliferation and repair of the epithelial cells (Sriwidodo et al., 2019), with the addition of hEGF, increasing the stability of autologous serum activity, improving the process of epithelialization, and healing can occur faster (Agung et al., 2016). Previously, we successfully produced hEGF in Escherichia coli but did not test its effects on epithelialization (Indriyani et al., 2019). Therefore, the activity of autologous serum, as well as the effect of the addition of vitamin $\mathrm{E}$ and recombinant hEGF in the treatment of epithelial damage, should be assessed.

Herein, we prepared dry autologous serum by freezedrying with the addition of sucrose. The stability of the serum components, EGF, TGF- $\beta 1$, fibronectin, and lysozyme, was assessed before the effects of the autologous serum with the addition of hEGF and vitamin $\mathrm{E}$ on the proliferation and migration of keratinocyte cells were determined.

\section{MATERIALS AND METHODS}

\section{Materials}

The materials used in the present study were human blood obtained from Indonesian Red Cross (PMI), recombinant hEGF from our previous study (Indriyani et al., 2019), vitamin E (Sigma Aldrich), methanol (Genetika Science), ethanol (Genetika Science), $n$-hexane (Genetika Science), diethyl ether (Merck), aquabidest (Genetika Science), standard retinol (Retinol lot BCBL 139V synthetic, $\geq 95 \%$ HPLC crystalline (Sigma Aldrich), kanamycin (Sigma Aldrich), keratinocyte cell culture from human cell line HaCat, RPMI-1640 media, dimethyl sulfoxide (DMSO) (Merck), (3-(4,5-Dimethylthiazol-2-yl)-2,5-Diphenyltetrazolium Bromide) (MTT) reagent (Merck), phosphate-buffered saline (PBS) (Merck), sucrose (Sigma Aldrich), Micrococcus lysodeikticus (Sigma Aldrich), sodium chloride (Merck), and Platinum ELISA Ready-to-use Sandwich ELISA (eBioscience).

\section{Preparation of autologous serum}

The blood samples were allowed to clot at $4^{\circ} \mathrm{C}$ for 2 hours and then centrifuged at 5,000 $\mathrm{g}$ for 10 minutes to obtain the serum, which was diluted with sterile physiological sodium chloride solution to give a final concentration of $20 \%(\mathrm{v} / \mathrm{v})$. The diluted serum was then divided into two groups; sucrose was added to one group to a final concentration of $60 \mathrm{mM}$. The serum samples were freeze-dried and stored at $4{ }^{\circ} \mathrm{C}$ and room temperature. The content of EGF, TGF- $\beta 1$, and fibronectin and also lysozyme activity were analyzed at $0,1,3$, and 6 months after storage. For activity assays, the diluted serum was filtered using a $0.2 \mu \mathrm{m}$ syringe, before the addition of vitamin $\mathrm{E}[0.5 \% ; 1 \%(v / v)]$, hEGF $(10,25 \mathrm{ng} / \mathrm{ml})$, and both vitamin $\mathrm{E}$ and $\mathrm{hEGF}(1 \% ; 25 \mathrm{ng} / \mathrm{ml})$. Untreated diluted serum was used as a control. The serum was added to RPMI-1640 media to a final concentration of $20 \%(v / v)$.

\section{Determination of EGF, TGF- $\beta 1$, and fibronectin content by ELISA}

EGF, TGF- $\beta 1$, and fibronectin content were determined using eBioscience ${ }^{\mathrm{TM}}$ Platinum ELISAs with a specific primary antibody for each protein according to the manufacturer's protocol.

\section{Determination of lysozyme activity by the turbidity method}

Each freeze-dried serum sample was diluted with aquabidest until a final volume of $1 \mathrm{ml}$. M. lysodeikticus cell suspension $(0.01 \% \mathrm{w} / \mathrm{v})$ in reaction buffer was used as a substrate. For the blank, $800 \mu \mathrm{l}$ of $M$. lysodeikticus cell suspension was added to cuvette and mixed with $30 \mu \mathrm{l}$ reaction buffer, and then the $\mathrm{A}_{450}$ was monitored. The $\mathrm{A}_{450}$ of the M. lysodeikticus cell suspension should be at $0.6-0.7$. For the standards and samples, $30 \mu \mathrm{l}$ lysozyme solution and $30 \mu \mathrm{l}$ serum solution were added to $800 \mu \mathrm{l}$ of $M$. lysodeikticus cell suspension and then mixed and the $\mathrm{A}_{450}$ was recorded every minute for 5 minutes.

\section{Determination of vitamin A content by HPLC}

The serum $(100 \mu \mathrm{l})$ was mixed with $100 \mu \mathrm{l} n$-hexane and centrifuged at $800 \mathrm{~g}$ for 5 minutes to collect the supernatant, which was evaporated in a water bath at $60^{\circ} \mathrm{C}$. The residue was suspended in $25 \mu \mathrm{l}$ diethyl ether and $75 \mu \mathrm{l}$ methanol. Standard retinol was dissolved with ethanol. Samples and standards were analyzed by analytical HPLC, equipped with a UV/Vis detector and $250 \mathrm{~mm} \mathrm{C}_{18}$ column, using methanol and water as the mobile phase [methanol: water $=95: 5(v / v)]$. The flow rate was set at $1 \mathrm{ml} /$ min and retinol was detected at $320 \mathrm{~nm}$.

\section{MTT proliferation assay}

Keratinocytes were cultured in RPMI-1640 media containing $5 \%$ calf serum and kanamycin $(100 \mu \mathrm{g} / \mathrm{ml})$. Cells were seeded in 96-well plates at a density of $2 \times 10^{4}$ cell cm $\mathrm{cm}^{-3}$ and incubated for 24 hours. The culture media were removed from the well, and then the well was washed with $100 \mu 1$ of $1 \times$ PBS before the addition of $100 \mu$ of the serum sample. The plates were incubated in a $\mathrm{CO}_{2}$ incubator for 48 hours. The wells were washed with $1 \times$ PBS, and then MTT reagents were added into each well for $10 \mu \mathrm{L}$ per $100 \mu \mathrm{L}$ medium and incubated for 4 hours. The reaction was stopped by the addition of DMSO and the absorbance was measured in a microplate reader at $450 \mathrm{~nm}$. The percent proliferation was determined as follows:

$$
\% \text { Proliferation }=\left(A_{\text {Treatment }} / A_{\text {Without Treatment }}\right) \times 100 \%
$$

\section{Scratch migration assay}

Keratinocytes were cultured and seeded into 96-well plates as before, then a scratch was made in the cell monolayer 
using a sterile tip and visualized. The culture media were removed from the well and the cells were washed with $500 \mu 1$ of $1 \times$ PBS, before the addition of $500 \mu \mathrm{l}$ of each serum sample. The plates were then incubated and observed after 18, 24, and 42 hours of incubation. The data were analyzed using TScratch software, with the percentage migration calculated as follows:

$\%$ cell migration $=($ area of the final stroke $/$ scratch area at 0 hour) $\times 100 \%$

\section{RESULTS}

\section{Preparation of autologous serum}

Autologous serum was separated from the blood cells (Fig. 1A), with the amount of serum collected from different donors ranging from 24 to $42 \mathrm{ml}$ (Geerling et al., 2004). The autologous serum was then diluted with sterile physiological sodium chloride, before the addition of sucrose. The serum samples were freezedried to yield a white-yellowish solid (Fig. 1B), which was then stored until further analysis.

\section{Preservation of autologous serum components during storage}

The content of EGF, TGF- $\beta 1$, and fibronectin of native autologous serum was $731.63 \mathrm{pg} / \mathrm{ml}, 62.33$, and $235.13 \mu \mathrm{g} / \mathrm{ml}$, respectively, while lysozyme activity was $1,133.33 \mathrm{Unit} / \mathrm{ml}$. The freeze-dried autologous serum was stored in both the refrigerator $\left(4^{\circ} \mathrm{C}\right)$ and room temperature. The EGF, TGF- $\beta 1$, and fibronectin content and lysozyme activity were determined after $0,1,3$, and 6 months (5 months for fibronectin) of storage (Fig. 2). Storage at a low temperature was more effective at preserving the autologous serum components compared to room temperature with or without the addition of sucrose. The addition of sucrose to autologous serum maintained a high EGF concentration throughout storage (Fig. 2A). Lysozyme activity and EGF concentration remained stable up to 6 months of storage in the refrigerator with or without the addition of sucrose (Fig. 2D), whereas TGF- $\beta 1$ and fibronectin concentration decreased after several months of storage (Fig. 2B and $\mathrm{C}$ ), and the presence of sucrose suppressed the decrease in the concentration of each component during storage. Hence, the addition of sucrose could preserve the freeze-dried autologous serum components for up to 6 months.

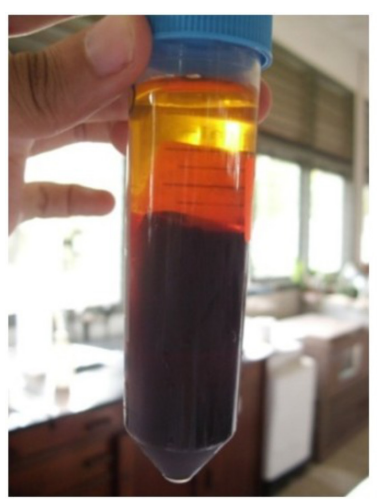

(A)

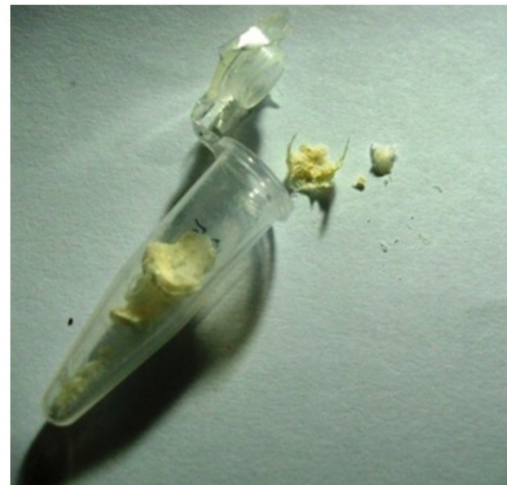

(B)
Figure 1. Preparation of autologous serum from donor blood: (A) centrifuged blood, the autologous serum is in the upper layer, and (B) freeze-dried autologous serum

\section{Vitamin A content in autologous serum}

The vitamin A content in the form of retinol was determined in autologous serum by reverse phase HPLC analysis (Fig. 3). Standard retinol has a retention time of 8.980 minutes, with the chromatogram of autologous serum from individual I and individual II characterized by a single peak at 8.709 and 8.723 minutes, respectively. A summary of retinol content determination is presented in Table 1, showing that there are differences in retinol levels in autologous serum from each individual, which is consistent with previous studies (Fischer et al., 2012; Geerling et al., 2004; Kand'ár et al., 2014; Quinto et al., 2008).

\section{EGF content of autologous serum}

The serum hEGF levels prior to the freeze-drying process are presented in Table 2, showing a difference between individuals. According to Geerling et al. (2004), serum hEGF levels are $0.5 \mathrm{ng} /$ $\mathrm{ml}$ in serum and $0.2-0.3 \mathrm{ng} / \mathrm{ml}$ in tears. The serum hEGF of each individual has a concentration that meets the hEGF concentration range in the tears. Therefore, the autologous serum could provide sufficient hEGF as a substitute for tears.

\section{Proliferation activity of autologous serum}

The percentage keratinocyte proliferation treated with autologous serum from each individual is shown in Figure 4, revealing that adding autologous serum alone to cells achieved $76.53 \%$ and $78.16 \%$ proliferation for individual I and individual II, respectively. The addition of hEGF or variation in vitamin $\mathrm{E}$ concentration in the autologous serum samples increased cell proliferation compared to autologous serum alone. Autologous serum with the addition of $1 \%$ vitamin E and hEGF $25 \mathrm{ng} / \mathrm{ml}$ induced the most proliferation, $89.82 \%$ and $96.55 \%$ for individual I and individual II, respectively. The pattern of cell proliferation was similar for both donors, although an increase in the percent cell proliferation was dependent on the individual autologous serum components.

\section{The effect of autologous serum on keratinocyte migration}

The percentage migration of keratinocytes induced by autologous serum was determined using TScratch software. The progression of the scratch width after $0,18,24$, and 42 hours of incubation is shown in Figure 5. The scratches were completely closed after 42 hours of incubation, indicating that the addition of autologous serum could induce the migration of keratinocytes. The percentage migration of keratinocytes treated with autologous serum from individual I and individual II with various treatments after 18, 24, and 42 hours of incubation is shown in Figure 6. The addition of hEGF 10 and $25 \mathrm{ng} / \mathrm{ml}$ to autologous serum increased cell migration compared to autologous serum alone. The addition of $0.5 \%$ vitamin $\mathrm{E}$ decreased cell migration, while $1 \%$ vitamin E increased cell migration comparable to the addition of $10 \mathrm{ng} /$ $\mathrm{ml}$ hEGF. Keratinocytes treated with autologous serum containing $25 \mathrm{ng} / \mathrm{ml} \mathrm{hEGF}$ and $1 \%$ vitamin $\mathrm{E}$ had $78.57 \%$ and $82.77 \%$ cell migration for individuals I and II, respectively, which was lower than autologous serum with the addition of $25 \mathrm{ng} / \mathrm{ml} \mathrm{hEGF}$. The pattern of cell migration was similar for both individuals I and II but the slight differences that arose between individuals I and II may be due to differences in their autologous serum content (Geerling et al., 2004). 


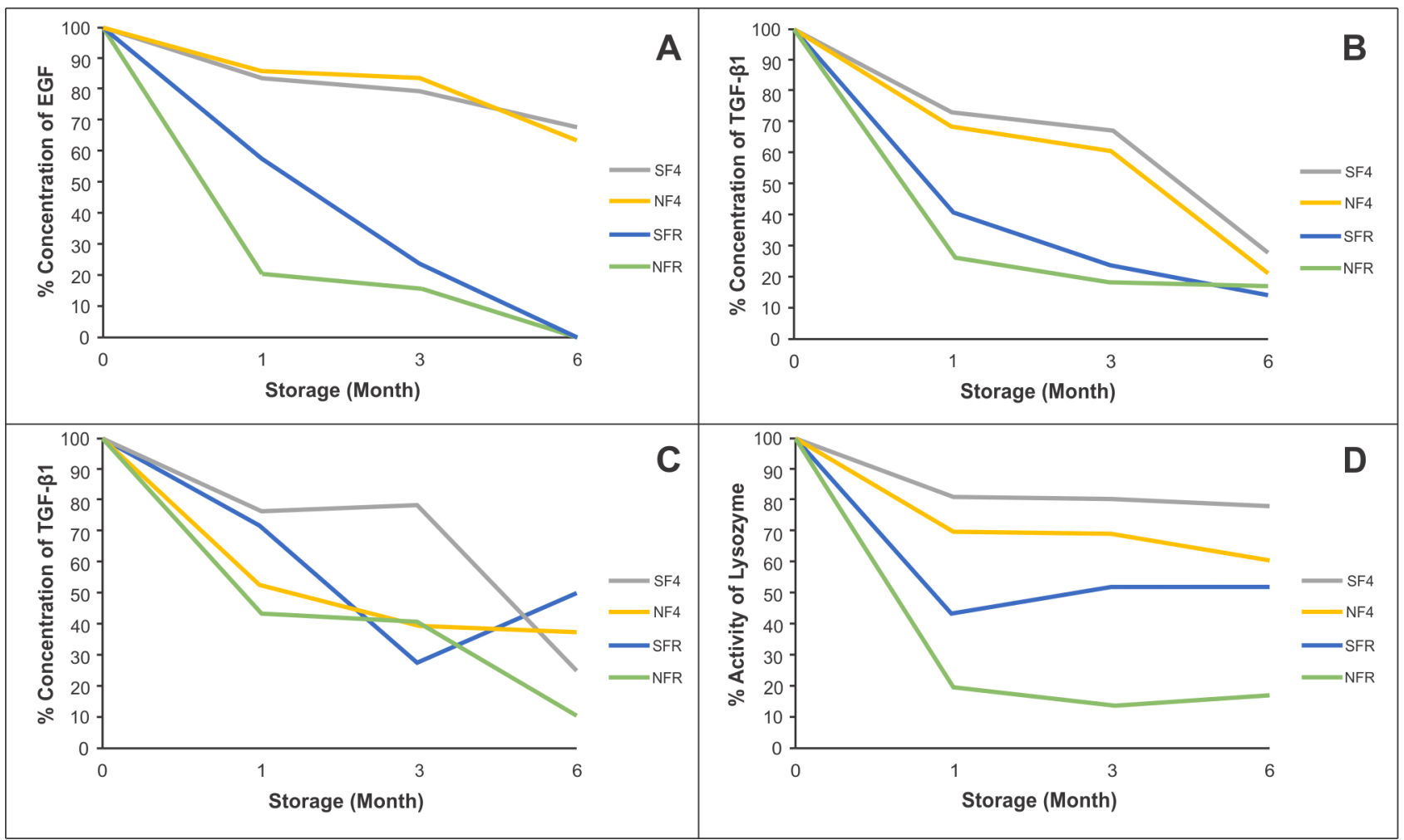

Figure 2. Stability of the autologous serum components during storage: (A-C) EGF, TGF- $\beta 1$, and fibronectin and (D) lysozyme activity. SF4: dried serum with the addition of sucrose at $4^{\circ} \mathrm{C}, \mathrm{NF} 4$ : dried serum without the addition of sucrose at $4^{\circ} \mathrm{C}$, SFR: dried serum with the addition of sucrose at room temperature, and NFR: dried serum without the addition of sucrose at room temperature.

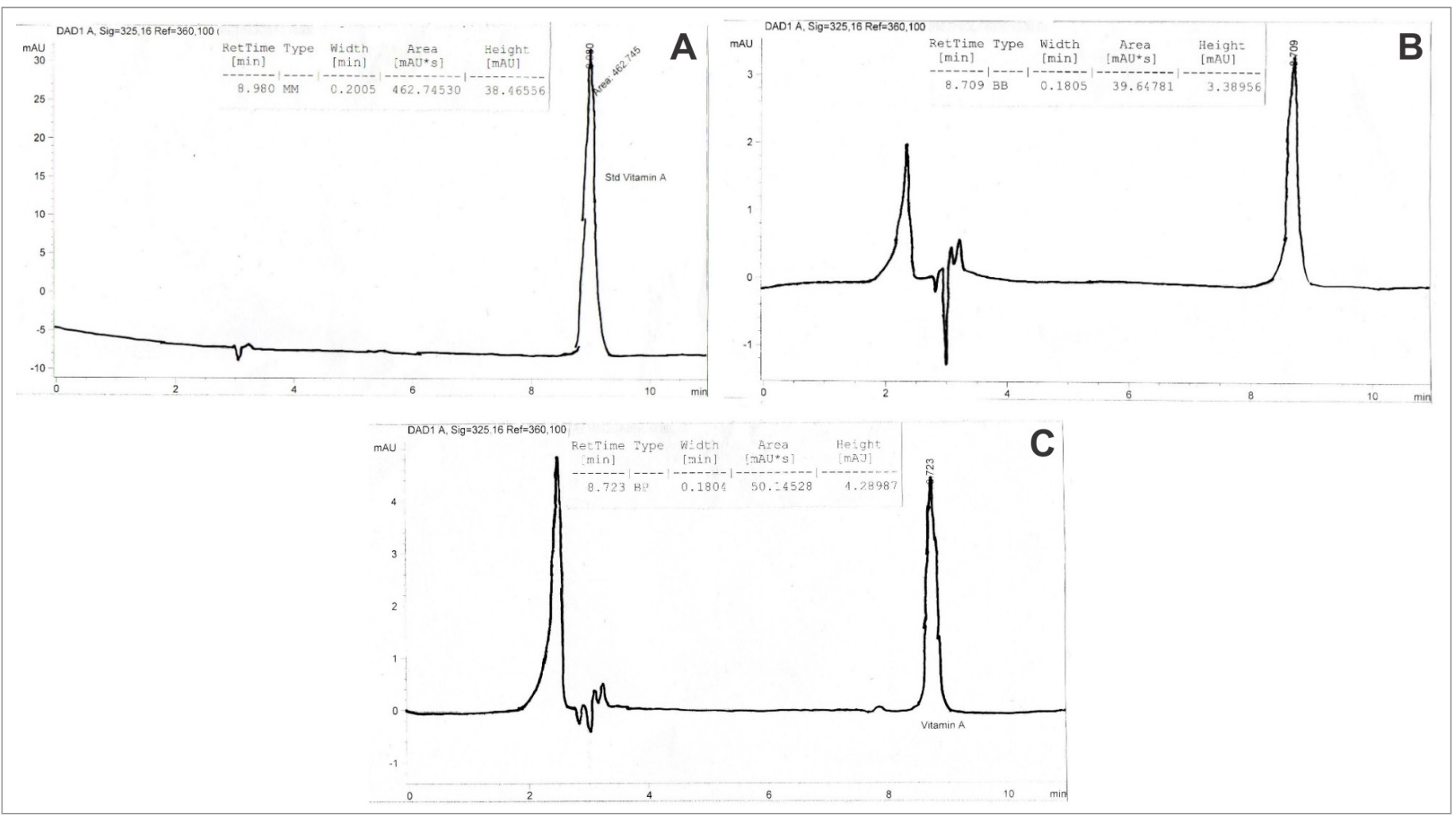

Figure 3. The chromatograms of retinol in autologous serum samples: (A) standard retinol $8 \mathrm{ppm}$, (B) autologous serum from individual I, and (C) autologous serum from individual II. 


\section{DISCUSSION}

The protocol for autologous serum collection used in the present study was based on protocol suggested by Liu et al. (2005), who reported that the serum obtained contained more EGF and consequently was a better treatment for dry eyes. The variation between the serum obtained from different donors was expected (Geerling et al., 2004). The freeze-drying process was approximately 24 hours in total, yielding a white-yellowish solid, which was resolubilized with sterile double distilled water to its original volume so that all components were in their original concentration before analysis.

Storage temperature influences the protein stability of solids, with the physical and chemical stability lower at a higher temperature (Wang, 2000). The storage of dried autologous serum at $4^{\circ} \mathrm{C}$ preserves the content of EGF, TGF- $\beta 1$, fibronectin, and lysozyme above the minimum concentration to replace the component in tears for up to 6 months. Sucrose acts as a stabilizer that can protect proteins in aqueous solutions, during both freezedrying and subsequent storage. It can protect the conformation of proteins in solids by forming hydrogen bonds that replace water

Table 1. Retinol concentration of autologous serum samples.

\begin{tabular}{lccc}
\hline Sample & $\begin{array}{c}\text { Retention time } \\
\text { (minutes) }\end{array}$ & Area (mAU.s) & $\begin{array}{c}\text { Retinol concentration } \\
\text { (ppm) }\end{array}$ \\
\hline Standard & 8.980 & 462,745 & 8 \\
Individual I & 8.709 & 39.6478 & 0.6854 \\
Individual II & 8.723 & 50.1453 & 0.8669 \\
\hline
\end{tabular}

The retinol concentration was determined using HPLC (with Waters 2998 photodiode array detector; Waters 1525 binary HPLC pump; column RP-18 endcapped $5 \mu \mathrm{m}$ Purospher STAR LiChroCART 250-4.6; flow rate $1 \mathrm{ml} /$ minutes; mobile phase being methanol : water $=95: 5)$.

Table 2. The hEGF levels of autologous serum samples. The hEGF levels were determined using ELISA.

\begin{tabular}{ccc}
\hline Sample & Absorbance & hEGF (ng/ml) \\
\hline Individual I & 0.1142 & 0.2964 \\
Individual II & 0.1367 & 0.5731 \\
\hline
\end{tabular}

A

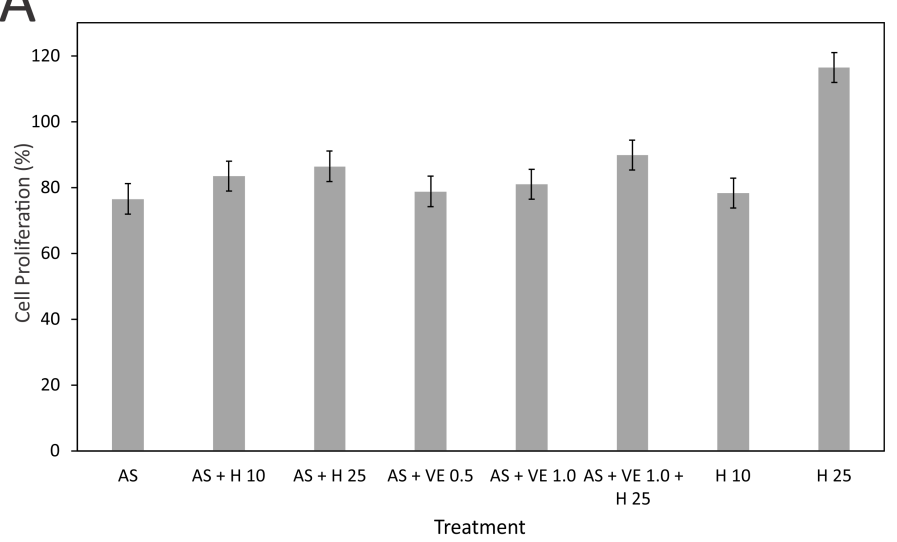

molecules around protein molecules (Cleland et al., 2001; Wang, 2000). The addition of sucrose to autologous serum was protective, combined with freeze-drying process and storage at $4^{\circ} \mathrm{C}$, which could preserve the concentration of autologous serum component as a substitute for tears in long-term storage.

Serum extraction using $n$-hexane is the best for extracting retinol (Kitagawa \& Hosotani, 2000), as evidenced by the peak in Figure 3. In line with previous studies, there was variation in blood serum retinol levels between individuals (Maksum et al., 2016, 2018).

The addition of autologous serum alone promoted keratinocyte proliferation, probably due to the endogenous hEGF content (Maksum et al., 2017; Sriwidodo et al., 2017). However, this was less than the percentage of cell proliferation induced by hEGF alone. The autologous serum contains other proteins in addition to hEGF which regulates gene expression, such as TGF- $\beta$. Cell proliferation is carefully controlled with EGF regulating cyclin $D$ gene expression involved in proliferation (Pecorino, 2012), while TGF- $\beta$ functions as a growth inhibitor (Zhang et al., 2017). As expected, the addition of hEGF (10 and $25 \mathrm{ng} / \mathrm{ml}$ ) increased keratinocyte proliferation more than autologous serum alone (Agung et al., 2016).

Autologous serum with the addition of vitamin E also has increased cell proliferation compared to autologous serum or $\mathrm{hEGF}$ alone. Vitamin $\mathrm{E}$ is an excellent antioxidant, preserving the retinol content in serum to achieve maximum stimulation of cell proliferation (Maksum et al., 2018; Niki, 2015). Inside the cell, retinol undergoes oxidation to retinoic acid, which is important for gene transcription related to cell growth and differentiation (Amann et al., 2011; Zasada \& Budzisz, 2019). The addition of 1\% vitamin $\mathrm{E}$ to autologous serum promoted more cell proliferation than $0.5 \%$ vitamin $\mathrm{E}$, consistent with previous work that showed that $1 \%$ vitamin $\mathrm{E}$ is better at stabilizing the retinol content during storage of dried autologous serum (Maksum et al., 2018). The addition of $25 \mathrm{ng} / \mathrm{ml} \mathrm{hEGF}$ and $1 \%$ vitamin $\mathrm{E}$ to autologous serum promoted the most keratinocyte proliferation, providing optimal conditions for cell proliferation.

The scratch assay was a well-known technique for cell migration assessment. The application of a scratch to

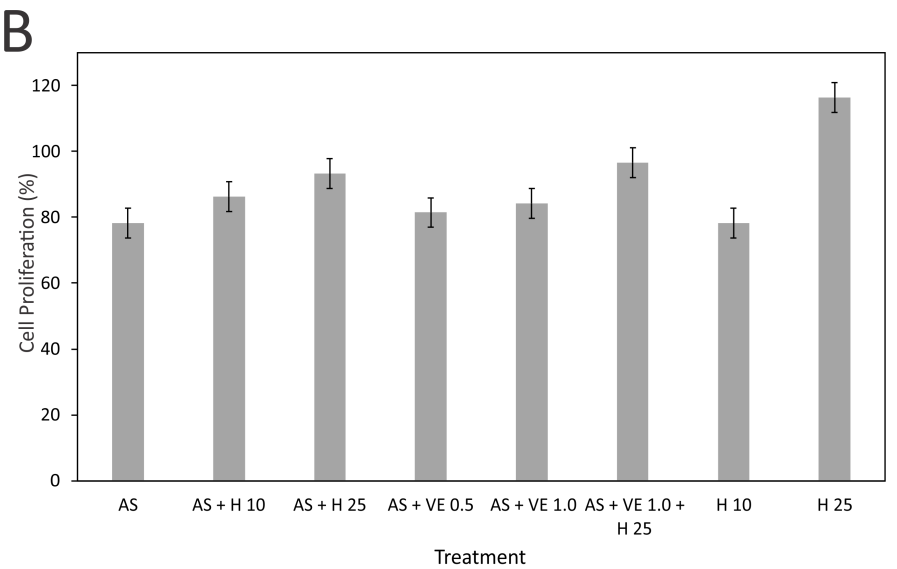

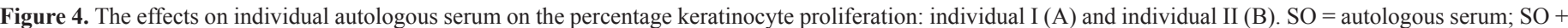

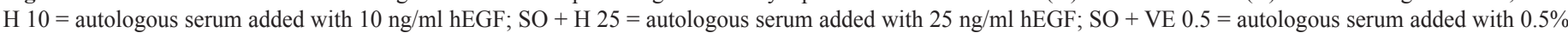

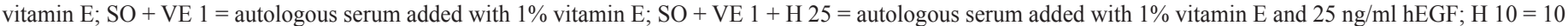
$\mathrm{ng} / \mathrm{ml}$ hEGF; H $25=25 \mathrm{ng} / \mathrm{ml}$ hEGF. Data are means of triplicate readings; error bar was represented. 

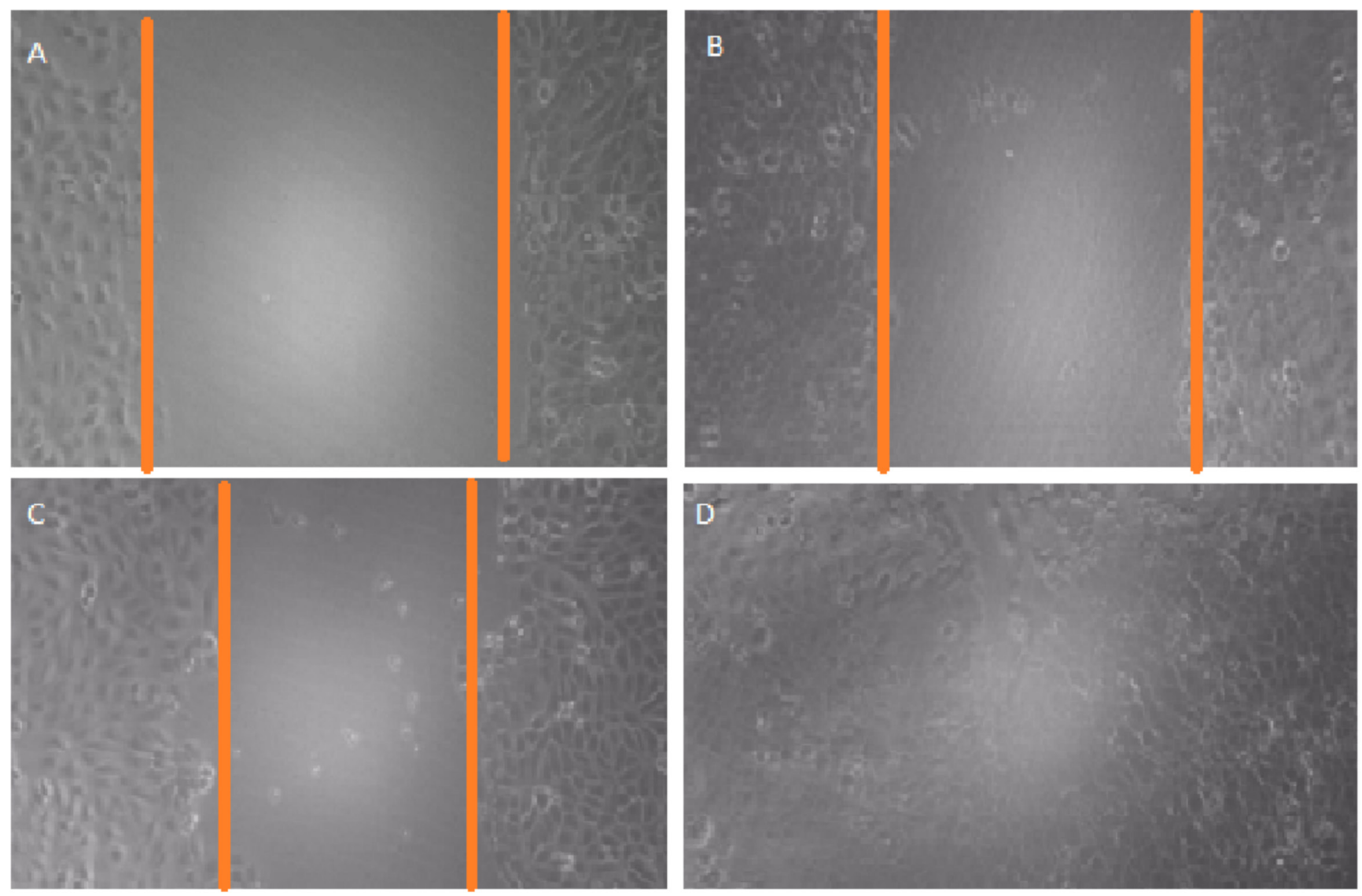

Figure 5. The effects of autologous serum from individual II containing $25 \mathrm{ng} / \mathrm{ml} \mathrm{hEGF}$ on keratinocyte migration assessed by the scratch assay: A= scratch at 0 hour, $\mathrm{B}=$ scratch at 18 hours, $\mathrm{C}=$ scratch at 24 , and $\mathrm{D}=$ scratch at 42 hours.

A

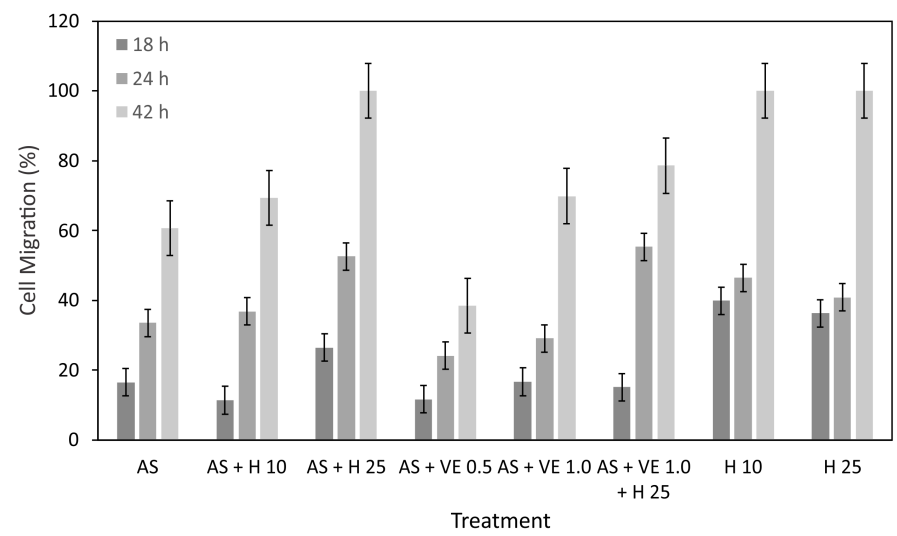

$\mathrm{B}$

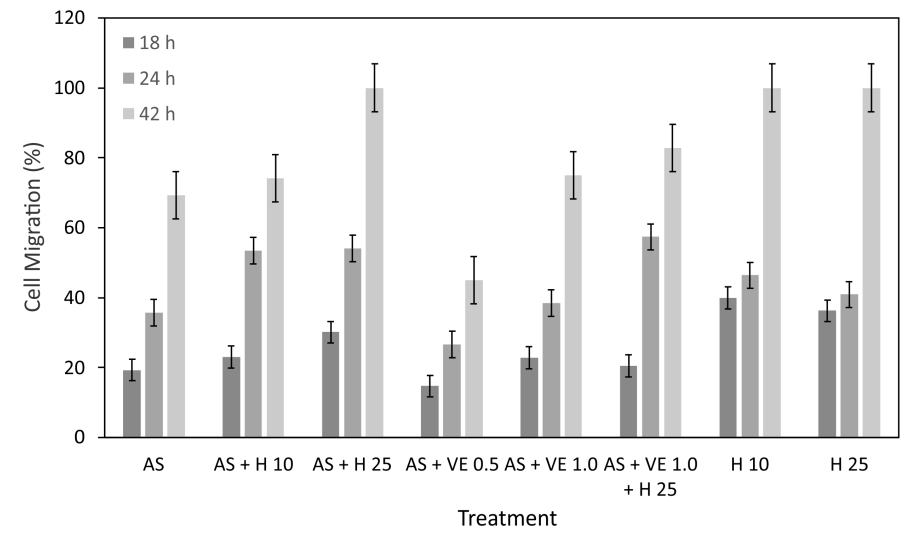

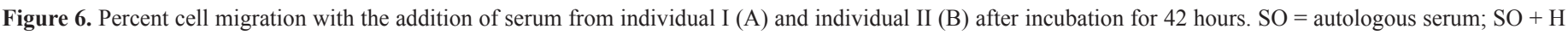

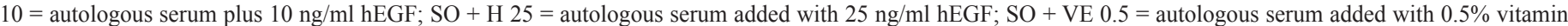

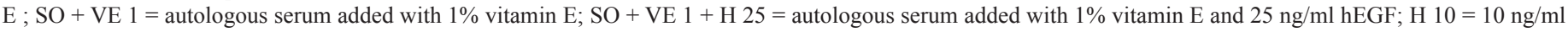
hEGF; H $25=25 \mathrm{ng} / \mathrm{ml}$ hEGF. Data are means of duplicate readings; error bar was represented.

keratinocyte cells created a scratch area, inducing cell migration as well as cell proliferation to close the area (Agung et al., 2016; Asmus et al., 2019; Javer et al., 2020). The autologous serum from both donors induced cell migration as evidenced by the closure of the scratch, which also occurred with autologous serum containing $25 \mathrm{ng} / \mathrm{ml} \mathrm{hEGF}$, as well as autologous serum containing $25 \mathrm{ng} / \mathrm{ml} \mathrm{hEGF}$ and $1 \%$ vitamin E. The addition of 10 and $25 \mathrm{ng} / \mathrm{ml} \mathrm{hEGF}$ as control induced scratch closure after 42 hours. According to Agung et al. (2016), the optimal concentration for the addition of hEGF alone for wound closure is $10 \mathrm{ng} / \mathrm{ml}$, while in this study $25 \mathrm{ng} / \mathrm{ml} \mathrm{hEGF}$ also provided optimal migration activity.

The differences in cell proliferation and migration induced by the serum from individuals I and II are related to 
differences in the autologous serum content, with individual II having higher levels of $\mathrm{hEGF}$ and retinol than individual I (see Tables 1 and 2), so that with the same treatment, there is a difference in the percentage proliferation.

\section{CONCLUSION}

In summary, in the present study, we found that the freeze-drying process can be useful to prolong the shelf life of autologous serum. Based on the content of EGF, TGF- $\beta 1$, and fibronectin as well as lysozyme activity analysis, the addition of sucrose can be useful to preserve the autologous component. The freeze-drying process and addition of sucrose are preserving serum components above the minimum requirement to substitute tears after 6 months of storage. The autologous serum itself can induce proliferation and migration of keratinocyte cells. The addition of $25 \mathrm{ng} / \mathrm{ml} \mathrm{hEGF}$ and $1 \%$ vitamin $\mathrm{E}$ to autologous serum can help increase its activity, indicated by increasing proliferation and migration of keratinocyte cells.

\section{ACKNOWLEDGMENT}

This work is supported by Academic Leadership Grant (ALG) Universitas Padjadjaran (no. 1427/UN6.3.1/LT/2020).

\section{CONFLICT OF INTEREST}

The authors report no financial or any other conflicts of interest in this work.

\section{PUBLISHER'S NOTE}

This journal remains neutral with regard to jurisdictional claims in published institutional affiliation.

\section{REFERENCES}

Agung SS, Maksum IP, Subroto T. Serum otologus dan human epidermal growth factor (hEGF) mempercepat proliferasi dan migrasi keratinosit pada proses re-epitelisasi. Majalah Kedokteran Bandung, 2016; 48(4):205-10.

Amann PM, Eichmuller SB, Schmidt J, Bazhin AV. Regulation of gene expression by retinoids. Curr Med Chem, 2011; 18(9):1405-12.

Asmus SE, Batey KG, Gale-Butto SN, Schmitt BL. Using the scratch assay to study cell migration in an inquiry-based cell biology lab. J Biol Educ, 2019; 53(2):157-64.

Carpenter JF, Crowe JH. An infrared spectroscopic study of the interactions of carbohydrates with dried proteins. Biochem, 1989; 28(9):3916-22.

Carpenter JF, Pikal MJ, Chang BS, Randolph TW. Rational design of stable lyophilized protein formulations: some practical advice. Pharm Res, 1997; 14(8):969-75.

Catignani GL, Bieri JG, Driskell WJ. Simultaneous determination of retinol and $\alpha$-tocopherol in serum or plasma by liquid chromatography. Clin Chem, 1983; 29(4):708-12

Cleland JL, Lam X, Kendrick B, Yang J, Yang TH, Overcashier $\mathrm{D}$, et al. A specific molar ratio of stabilizer to protein is required for storage stability of a lyophilized monoclonal antibody. J Pharm Sci, 2001; 90(3):310-21

Fischer KR, Opitz A, Böeck M, Geerling G. Stability of serum eye drops after storage of 6 months. Cornea, 2012; 31(11):1313-8.

Geerling G, MacLennan S, Hartwig D. Autologous serum eye drops for ocular surface disorders. Br J Ophthalmol, 2004; 88(11):1467-74.

Hermeling S, Crommelin DJA, Schellekens H, Jiskoot W. Structure-immunogenicity relationships of therapeutic proteins. Pharm Res, 2004; 21(6):897-903.

Herrero-Vanrell R, Molina-Martínez I. Autologous serum in the treatment of dry eye sindrome. Technological aspects. Arch Soc Esp Oftalmol, 2008; 83(9):521-3.
Indriyani A, Indrayati N, Sriwidodo S, Maksum I. Optimization extracellular secretion of recombinant human epidermal growth factor (hEGF) in Escherichia coli BL21 (DE3) pD881-OmpA-hEGF by using response surface method (RSM). Int J Res Pharm Sci, 2019; 10:1824-31.

Javer A, Rittscher J, Sailem HZ. DeepScratch: single-cell based topological metrics of scratch wound assays. Comput Struct Biotechnol J, $2020 ; 18: 2501-9$.

Kand’ár R, Drábková P, Myslíková K, Hampl R. Determination of retinol and $\alpha$-tocopherol in human seminal plasma using an HPLC with UV detection. Androl, 2014; 46(5):472-8.

Kitagawa M, Hosotani K. Improved method of determining retinol and retinyl palmitate in rat liver and serum by high-performance liquid chromatography. J Nutr Sci Vitaminol, 2000; 46(1):42-5.

Koffler BH. Autologous serum therapy of the ocular surface with novel delivery by platelet concentrate gel. Ocul Surf, 2006; 4(4):188-95.

Liu L, Hartwig D, Harloff S, Herminghaus P, Wedel T, Geerling G. An optimised protocol for the production of autologous serum eyedrops. Graefes Arch Clin Exp Ophthalmol, 2005; 243(7):706-14.

López-García JS, García-Lozano I, Rivas L, MartínezGarchitorena J. Use of autologous serum in ophthalmic practice. Arch Soc Esp Oftalmol, 2007; 82(1):9-20.

Maksum IP, Indrayati L, Enus S. Stabilisasi vitamin A (retinol) pada serum otologus sediaan serbuk kering menggunakan lioprotektan sukrosa. J Chim Nat Acta, 2016; 4(2):106-10.

Maksum IP, Subroto T, Sriwidodo S, Harita AFP, Kurniawansyah IS. Stabilization of vitamin A using vitamin $\mathrm{E}$ as antioxidant in lyophilized autologous serum and its antibacterial properties. Int Res J Pharm, 2018; 9(7):79-84

Maksum IP, Utama E, Sriwidodo S, Subroto T. Extracellular secretion of recombinant human epidermal growth factor by using trimethylamine $\mathrm{N}$-oxide reductase A (TorA) signal peptide in Escherichia coli BL21 (DE3). J Pharm Sci Res, 2017; 9(6):1007-16.

Niki E. Evidence for beneficial effects of vitamin E. Korean J Intern Med, 2015; 30(5):571-79.

Pecorino L. Molecular biology of cancer: mechanisms, targets, and therapeutics. Oxford University Press, Oxford, UK, 2012.

Quinto GG, Campos M, Behrens A. Autologous serum for ocular surface diseases. Arq Bras Oftalmol, 2008; 71(6):47-54.

Sriwidodo S, Maksum IP, Riswanto N, Rostinawati T, Subroto T. Extracellular secretion recombinant of human epidermal growth factor (hEGF) using pectate lyase B (PelB) signal peptide in Escherichia coli BL21(DE3). Int J Res Pharm Sci, 2017; 8:33-40.

Sriwidodo S, Subroto T, Maksum IP, Wathoni N, Rostinawati T, Ulya H, Putri IU. Optimization of secreted recombinant human epidermal growth factor production using pectate lyase B from Escherichia coli BL21(DE3) by central composite design and its production in high cell density culture. J Pharm Bioallied Sci, 2019; 11(Suppl 4):S562-6.

Tang XC, Pikal MJ. Design of freeze-drying processes for pharmaceuticals: practical advice. Pharm Res, 2004; 21(2):191-200.

Wang W. Lyophilization and development of solid protein pharmaceuticals. Int J Pharm, 2000; 203(1-2):1-60.

Zasada M, Budzisz E. Retinoids: active molecules influencing skin structure formation in cosmetic and dermatological treatments. Postepy Dermatol Alergol, 2019; 36(4):392-7.

Zhang Y, Alexander PB, Wang XF. TGF- $\beta$ family signaling in the control of cell proliferation and survival. Cold Spring Harb Perspect Biol, 2017; 9(4):1-22.

How to cite this article:

Maksum IP, Jubaedah S, Yosua Y, Melpin R, Rondonowu M, Enus S, Rachman SD, Sriwidodo S, Subroto T. Lyophilized autologous serum stabilized with sucrose promotes the proliferation and migration of keratinocyte. J Appl Pharm Sci, 2021; 11(07):110-116 